\title{
Thematization in Polish Current Affairs TV Programmes During 2014 European Election Campaign: Autopoiesis In Polish Media System
}

\author{
Tomasz Gackowski, Warsaw University. Poland
}

\begin{abstract}
The aim of this study was to examine the quality of Polish public debate on the European Elections: in other words, how current affairs TV programmes tried to explain the complexity of issues concerning the European Union and the essence of the functioning of the European Parliament to the average viewer-voter. In the study, the methodology of qualitative and quantitative content analysis was implemented.

The paper focuses on the phenomenon of thematization in the TV programmes covered in the study. Much attention in the discussions of the journalistic topics was given to such issues as the process and dynamics of a given campaign, the manner of its coverage by the media, and the polls. In this regard, the results of the study confirmed a strong autopoietic (definition of the Luhmann's theory) and self-referential nature of the electoral discourse.
\end{abstract}

Keywords: thematization, topics, current affairs TV programmes, discourse, autopoietic 


\section{Research}

In this paper, the author would like to present some results of the complex research conducted in 2014, particularly two weeks before the European Elections in Poland (10-23 May 2014). The purpose of the study was to analyse the quality of the journalistic discourse during the electoral period and to see how current affairs TV programmes, covered in the study, tried to explain the complexity of issues concerning the European Union and the essence of the functioning of the European Parliament to the average viewer-voter. The research was based on the qualitative and quantitative analysis of the content of the current affairs television programmes (complex code key, charts of quality analysis for each programme, and transcriptions of journalists' statements). The research material contains all current affairs TV programmes in which candidates to EP appeared or in which topics related to the EP Elections were raised within two weeks before the European Elections, that is in the period between 10 and 23 May 2014. The study encompassed the following Polish nationwide stations - TVP1, TVP2, TVN24, Polsat News, TVP Info, TV Trwam (55 hours of study in total). The first graph below presents the exact number of unique TV materials, devoted solely to the elections, from the whole research sample (in total: 160 unique current affairs TV programmes)

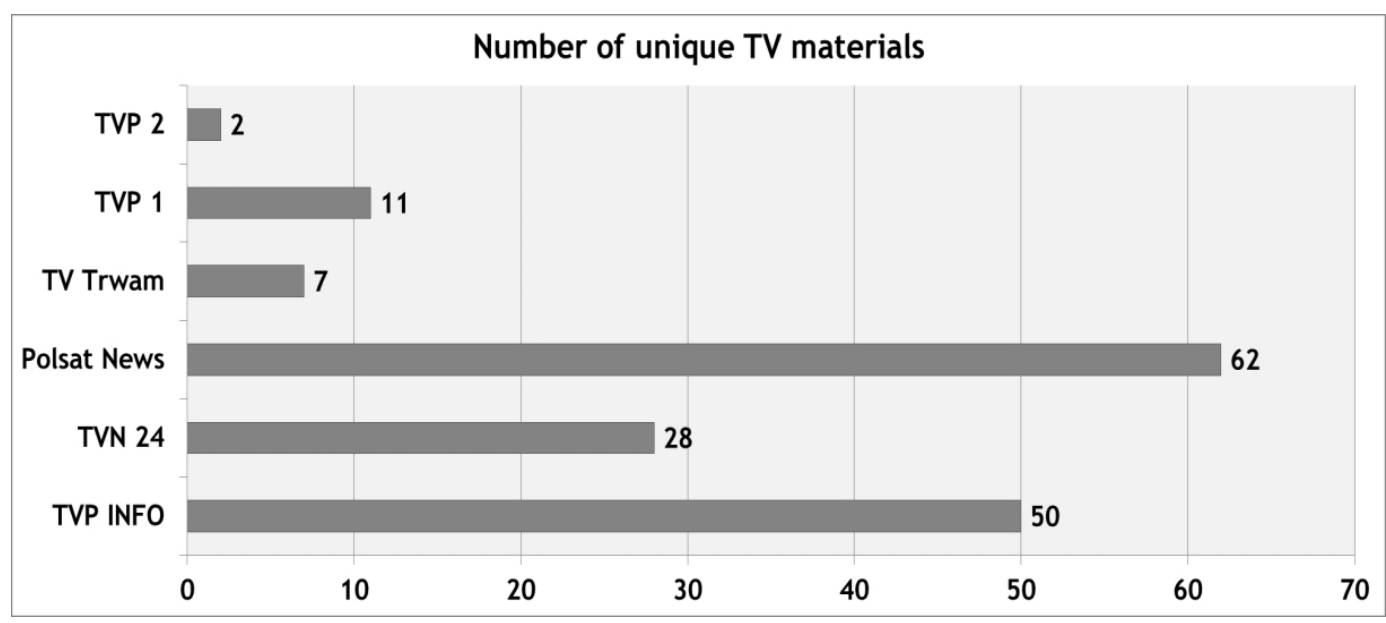

Graph no. 1. Source: own research

It is worth mentioning that these channels broadcast the most popular current affairs TV programmes. Three of them, TVP1, TVP2, and TVP Info, are publicly owned. It must be underlined that TVP INFO is a typical news dedicated channel, which is a part of the Polish national public broadcaster - TVP (TVP 1 and TVP 2 are mainstream channels, that are not entirely dedicated to news broadcasting). TVN24 and Polsat News are the news channels owned by the two main competitors of TVP - TVN and Polsat, which are private, commercial TV stations. Finally, there is also TV Trwam, which is the biggest social and catholic broadcaster - non-private and non-public (according to the license, it cannot emit commercials). In general, TV Trwam is in great opposition to the rest of the channels, both in terms of programmers that are broadcasted and its political affiliation. We have to add that the voice of TV Trwam is one of the most influential ones in the Polish discourse and therefore, the study cannot ignore it and focus only on the mainstream TV news stations.

In the research that was conducted on the request of the Polish National Broadcasting Council, a research team studied various aspects of the political discourse in the current affairs TV programmes, including: structure of the programmes (construction (parts of the programmes), visuals, video editing), guests and anchors of the programmes (type of guest, 
affiliation, place, and time of exposure (passive (appearing without saying anything) / active (appearing and talking)), rhetoric, argumentation strategies, interactions with journalist and opponents, the number of interrupts (style of interrupting), anchors' style of delivery (meaningful verbal and non-verbal behaviours), questioning strategies, interactions with guests and self-presentation (including topics discussed and knowledge presented on air), the role and image of women (women as guests (number - proportion to men, guest type, style of communication, conversational style), women as anchors (as above)), missionary values of the television (according to Polish law): pluralism, impartiality, balance, integrity and quality, and finally, thematization - the main focus of this paper - which includes topics that were discussed, time devoted to each topic, and also the self-reference of the media system.

\section{Exposure of Political Parties during 2014 European Campaign in Poland}

Because of the space constraints, the author would like to focus only on two aspects of the aforementioned study. The first aspect is related with the following questions: how did the structure of a given party's TV exposure, in the last two weeks before the European Elections, eventually influence the electoral results? Are these two issues correlated? If they are, what does it mean? Another question that is to be raised is connected with the idea of the media thematization on the European Campaign - what it was about and what kind of topics built the political discourse during the last days before the elections.

The second graph below shows the presence of the electoral committees of particular political parties on air (in minutes).

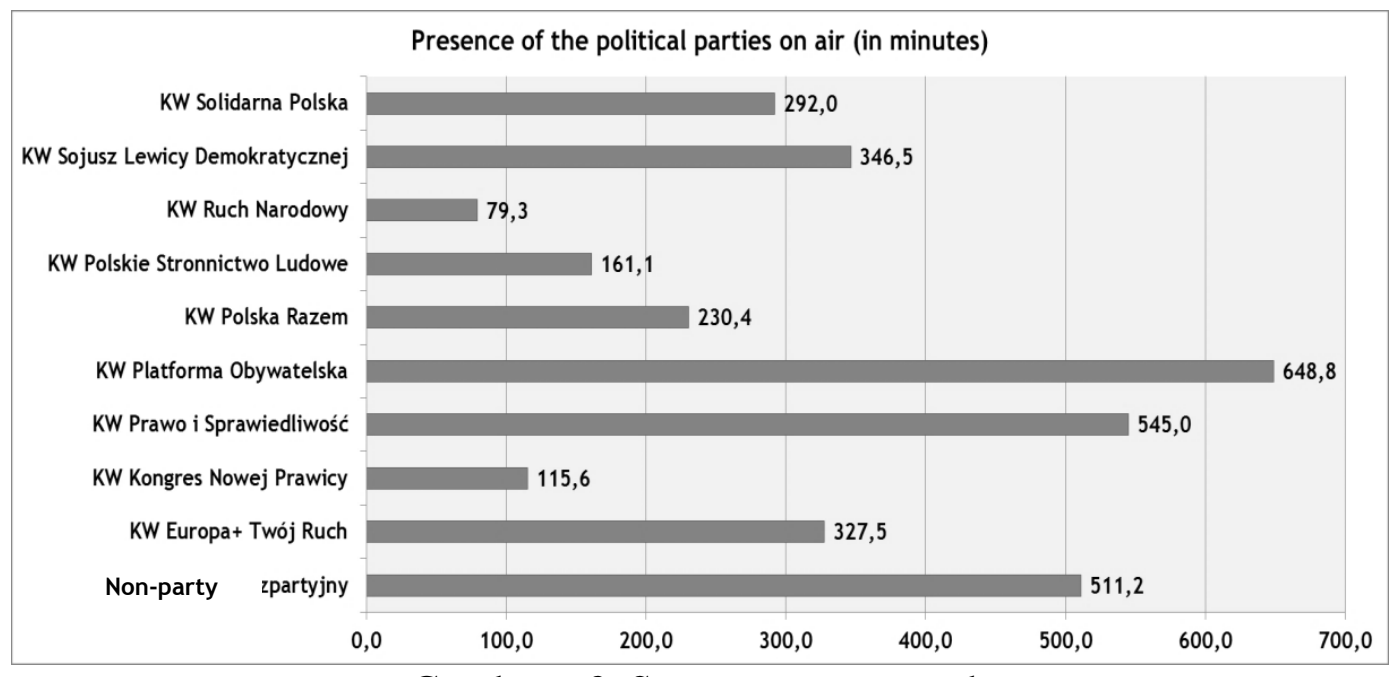

Graph no. 2. Source: own research

Two main parties - Platforma Obywatelska (Civic Platform - the governing party) and Prawo i Sprawiedliwość (Law and Justice - the main opposition party) - were most frequently presented in the programmes covered in the analysis. A group of experts, advisers, spin doctors, former politicians, and officials - named as "Non-party" - ranked third. The second governing party (a smaller coalition partner) - Polskie Stronnictwo Ludowe (Polish People's Party) - received only 161.1 minutes of exposure. It was twice less than two other Polish parliamentary opposition parties - Sojusz Lewicy Demokratycznej (Democratic Left Alliance) and Europa+ Twój Ruch (Europe+ Your Move). If we look closer at the next graph (Graph no. 3), which presents the structure of exposure in every TV station included in the research, we will see that all three news stations tried to present various electoral committees. 


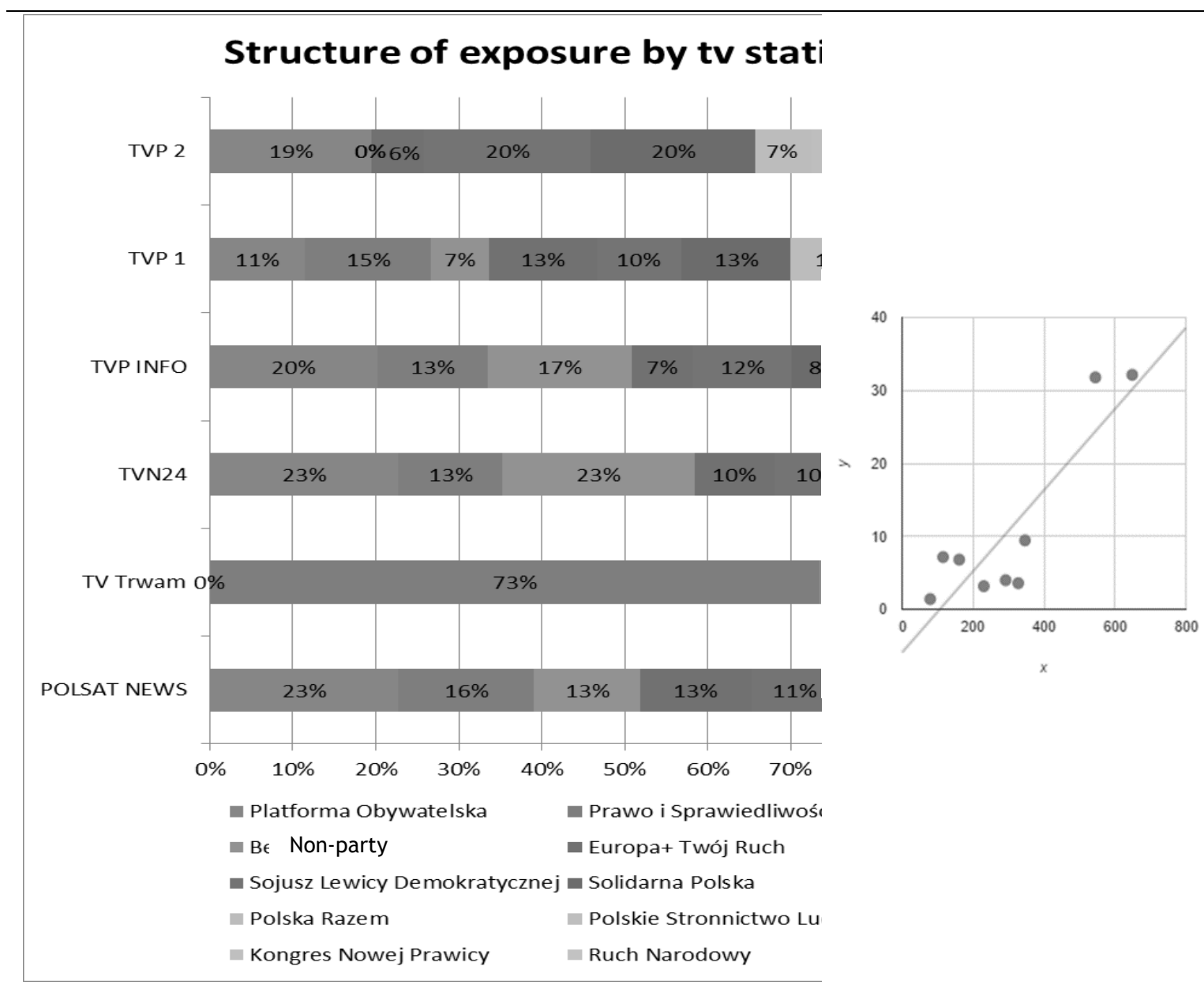

Graph no. 3. Source: own research

Generally, the more diverse the graph, the greater the pluralism of a given television station. Furthermore, the more evenly and symmetrical the greyscale in the graph appear, the greater the impartiality of a given station is - of course, if we make a simplification and decide to measure the exposure of the political parties as the main determinant. At this point, it should be noted that there is a great disproportion when it comes to TV Trwam. This social and religious TV station is strongly affiliated with the right wing parties which are, at the moment, in opposition - Prawo i Sprawiedliwość (Law and Justice) and Polska Jest Najważniejsza (Poland Comes First). Therefore, these two political groups received the greatest amount of airtime. The third group which was given some amount of coverage in TV Trwam consisted of experts, advisers, and social activists. Other stations tried to provide a more or less similar amount of airtime for all electoral committees.

Now, if we take into account the relation between the media exposure - the visibility in the current affairs TV programmes, broadcasted within the last two weeks before the 2014 European Elections - and the final results achieved by each electoral committee, we will notice that they are not accidental, but correlated. We believe that there is an even stronger correlation between being in the current affairs TV programmes and achieving proportional electoral results. The following charts and tables present the r-Pearson correlations. Table no. 1 and graph no. 4 show the general correlations between the exposure of electoral committees on TV and their electoral results. 
Linear r-Pearson correlations: structure of exposure vs elections results

\begin{tabular}{|c|c|c|}
\hline $\begin{array}{c}\text { European } \\
\text { Elections } \\
\mathbf{2 0 1 4}\end{array}$ & $\begin{array}{c}\text { Exposure in } \\
\text { minutes }\end{array}$ & $\begin{array}{c}\text { Electoral results } \\
\text { (pct.) }\end{array}$ \\
\hline PO & 648.8 & 32.13 \\
\hline PiS & 545 & 31.78 \\
\hline SLD & 346.5 & 9.44 \\
\hline E+TR & 327.5 & 3.57 \\
\hline SP & 292 & 3.98 \\
\hline PR & 230.4 & 3.16 \\
\hline PSL & 161.1 & 6.8 \\
\hline KNP & 115.6 & 7.15 \\
\hline RN & 79.3 & 1.39 \\
\hline
\end{tabular}

Table no. 1 and Graph no. 4. Source: own research

\begin{tabular}{|l|}
\hline r-Pearson : 0,877 \\
\hline$\alpha: 0,002$ \\
\hline
\end{tabular}

Table no. 2. Source: own research

\begin{tabular}{|c|c|c|}
\hline TVP INFO & POLSAT NEWS & TVN24 \\
\hline r-Pearson: 0.852 & r-Pearson $: 0.823$ & r-Pearson $: 0.793$ \\
\hline$\alpha: 0.004$ & $\alpha: 0.006$ & $\alpha: 0.011$ \\
\hline
\end{tabular}

\begin{tabular}{|c|c|c|c|c|c|c|}
\hline $\begin{array}{c}\text { European Elections } \\
\text { 2014 }\end{array}$ & \multicolumn{2}{|c|}{ TVP Info } & \multicolumn{2}{c|}{ Polsat News } & \multicolumn{2}{c|}{ TVN24 } \\
\hline $\begin{array}{c}\text { Structure of time } \\
\text { exposure by Polish } \\
\text { TV stations and } \\
\text { electoral results }\end{array}$ & $\begin{array}{c}\text { Exposure } \\
\text { (pct.) }\end{array}$ & $\begin{array}{c}\text { Results } \\
\text { (pct.) }\end{array}$ & $\begin{array}{c}\text { Exposure } \\
\text { (pct.) }\end{array}$ & $\begin{array}{c}\text { Results } \\
\text { (pct.) }\end{array}$ & $\begin{array}{c}\text { Exposure } \\
\text { (pct.) }\end{array}$ & $\begin{array}{c}\text { Results } \\
\text { (pct.) }\end{array}$ \\
\hline PO & 20 & 32.13 & 23 & 32.13 & 23 & 32.13 \\
\hline PiS & 13 & 31.78 & 16 & 31.78 & 13 & 31.78 \\
\hline SLD & 12 & $9 ., 44$ & 11 & 9.44 & 10 & 9.44 \\
\hline E+TR & 7 & 3.57 & 13 & 3.57 & 10 & 3.57 \\
\hline SP & 8 & 3.98 & 8 & 3.98 & 8 & 3.98 \\
\hline PR & 7 & 3.16 & 6 & 3.16 & 8 & 3.16 \\
\hline PSL & 8 & 6.8 & 4 & 6.8 & 2 & 6.8 \\
\hline KNP & 6 & 7.15 & 3 & 7.15 & 5 & 7.15 \\
\hline RN & 1 & 1.39 & 3 & 1.39 & 0 & 1.39 \\
\hline
\end{tabular}

Table no. 3. Source: own research 
TVP INFO

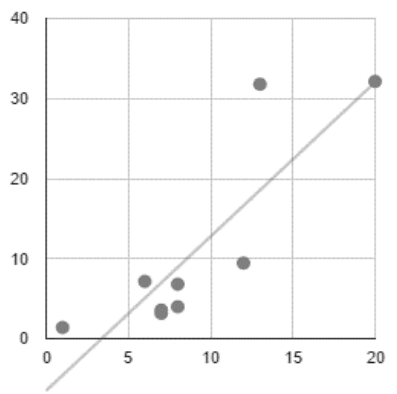

POLSAT NEWS

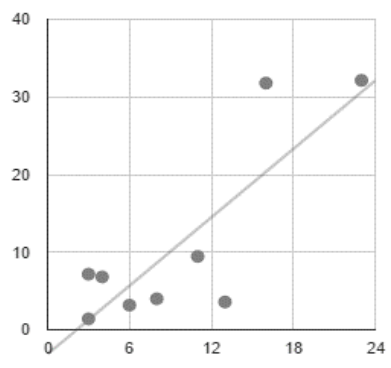

TVN24

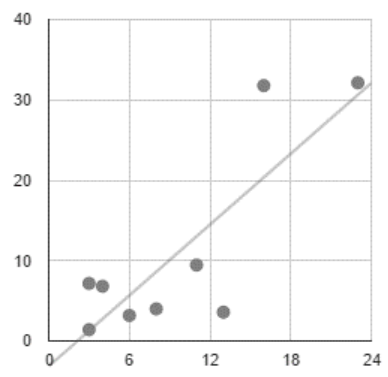

Graphs no. 5-7. Source: own research

Almost all tables and graphs presented above show a significant linear r-Pearson correlation between the visibility of particular parties in the current affairs TV programmes within the last two weeks before the European Elections and their final electoral results. In general - in table no. 1 and graph no. 4 - we can see that the correlations are really strong, with $\alpha: 0.002$ and r-Pearson: 0.877. If we take a precise look at the rest of the tables (no. 2-3) and charts (no. 5-7), we can notice that this general correlation is also maintained in the case of the two TV news channels covered in the research - TVP INFO (the biggest correlation and a great level of significance) and Polsat News (also big correlations, but with a lower level of significance). The weakest correlation was discovered in the case of TVN24 (r-Pearson : $0.793 ; \alpha: 0.011)$.

As we may see, this simple data summary could be supportive of the following thesis: if your exposure in the current affairs TV programmes within the last two weeks before the European Elections is high, you will receive better electoral results. However, this intuitive assumption does not have to be true in every case. We have to bear in mind that the linear correlation values presented above are heavily based on the two main and biggest parties, PO (Civic Platform) and PiS (Law and Justice). If we eliminate these two parties from the graph/table and leave only the small ones, the correlation between the exposure of these parties in the TV news stations and their electoral results will be much lower, a mere 0.44 . One could say that the globally dominant parties are heavily exposed, but the smaller ones are only slightly exposed. However - according to the latter remark - we can say, in simple terms, that the smaller a party is, the lower the r-Pearson correlation between the electoral results and the exposure of this very party on TV is noted. It turns out that the dependence the exposure on TV and the electoral results can be noticed only if we take into consideration the dominant parties.

For now, it is worth remembering that these observations may be primarily related with the specificity of elections, particularly in the case of the European Elections. We do not have enough space to present other variables of the political discourse that were analysed in terms of their correlation with electoral results, however, we have to say that there are numerous studies and a great deal of research which prove that the European Elections do not have to be perceived on par with other elections that take place in any democratic country. In other words, according to Reif and Schmitt (1980), the European Elections seem to be the so-called Second-Order Elections (SOE). The First-order Elections (FOE) are of course the national elections. What is more, the results and campaigns of the European Elections - from the SOE's perspective - are influenced by the political constellation of a national political arena 
and are characterized by the dominance of the first-order arena national political issues (Reif and Schmitt, 1980: 247). In this case, we have to remember about the very important concept of Europeanization (Börzel and Risse, 2003; Cowles et al., 2001; Featherstone and Radaeli, 2003; Ladrech, 2010). The Europeanization is understood as a process by which domestic actors and institutions adapt to the institutional framework and logic of the EU or, in other words, as the responses of national actors to the impact of the European integration (Ladrech, 2002: 392-393; Radaelli, 2000, Kovár and Kovár, 2012: 32). From this point of view, the Europeanization, treated as a media's logic process, presents different ways of how political parties wage the EP Election campaigns. The media seem to be a good platform for an analysis of how political actors deal with the issues associated with the European integration during the EP Elections (Kriesi, 2007: 90).

After more than three decades and six rounds of the EP Elections, the SOE model has, by and large, become one of the most widely tested and supported theories of a voting behaviour in the elections to the EP (e. g. Ferrara and Weishaupt, 2004; Freire and Teperoglou, 2007; Hix and Marsh, 2007). We should also be aware of the fact that the media constitute the most important source of political information and provide a channel of communication between the governors and the governed, particularly in relation to such a remote and abstract issue as the European Union (EU) politics. It is also an important channel of information in the case of the Second-Order EP Elections (Strömbäck and Shehata, 2010; Blumler, 1983; Koopmans, 2007, Bennett and Entman, 2001; European Commission, 2004: 162). Given the highly "national" structure of the EP Elections and their identification as SOEs, where the national political arena provides the dominant frame of reference, it is hardly surprising that the campaigns should be nationally differentiated.

\section{Thematization of Polish Discourse during 2014 European Elections}

According to the aforesaid observations, the following questions arise: to what extent do the Polish current affairs TV programmes present the most important information about the EU and the challenges which the European Union and, consequently, the European Parliament, along with their representatives, are facing? What kind of tasks and topics are they dealing with? Finally, what kind of an institution is the European Parliament? What can and cannot the EPs do? What kind of pledges can they make?

The majority of the answers to these questions seem to be hidden in one of the most important categories of this study, namely the thematization of the political discourse in the Polish current affairs TV programmes (see f. ex.: Boyatzis 1998; Jalali \& Silva, 2011, Bolin, 2014, Hollander, 2014). In other words, it concerns the question of what topics and threads were mainly discussed by the anchors and their guests during the programmes covered in the study.

First of all, in the research, we described 841 thematic units (one topic discussed in one programme was classified as one unit), with two levels of coding. Generally, we have identified:

- 623 unique thematic units aggregated at a detailed level;

- 185 thematic categories aggregated at a generalized level.

What has to be emphasized is the fact that out of the 185 thematic categories [clusters] aggregated at the generalized level - clustered level (according to Krippendorff, 1980) - top ten categories constitute almost 66 percent of the 841 thematic units that were identified. 
These categories were classified as thematic units and are listed in the following table, along with the percentage and the total number of occurrence.

\begin{tabular}{|c|c|c|}
\hline Subject & Number of occurrence & Percentage of all subjects \\
\hline Electoral campaign itself & 302 & $36 \%$ \\
\hline $\begin{array}{c}\text { The current politics of the } \\
\text { parties }\end{array}$ & 76 & $9 \%$ \\
\hline Polls & 55 & $7 \%$ \\
\hline Statements of assets & 31 & $4 \%$ \\
\hline Quality of public debate & 24 & $\mathbf{3 \%}$ \\
\hline Ukrainian crisis & 21 & $\mathbf{2 \%}$ \\
\hline Energy union & 16 & $\mathbf{2 \%}$ \\
\hline Integration deepening & 11 & $1 \%$ \\
\hline Flood protection & 10 & $1 \%$ \\
\hline Self-presentation of politics & $\mathbf{8}$ & $1 \%$ \\
\hline
\end{tabular}

Table no. 4. Source: own research

What should be added is the fact that the primary sets of information, encoded for all the programmes covered in the study, consisted of the topics that were discussed in each of these programmes. As a separate topic, we also encoded each single thread in the discussion, the so-called interjections made by the journalists or one of the guests, which introduced a new issue that was, nevertheless, not discussed further in the programme. A surprising observation can be drawn from the results presented in table no. 4, namely the strength of the autopoetic (Luhmann, 2000) materials in the journalism devoted to the EP Elections (See: Schuck et. al., 2013). A very high percentage of discussions held by the journalists concerned, to a greater or lesser extent, the campaign itself - its style, rhetoric employed by various parties, electoral spots, communication strategies, etc. The topics related to the campaign were also strongly connected with the currently published polls, the reflections on the quality and level of the public debate, and the self-presentation of particular politicians. The substantive issues outside the scope of the campaign, concerning practical political problems, were clearly dominated by the general topics, not related to the current political decisions, in the discourse of the television programmes covered in the study. The main theme of the broadcast journalism - tackled beyond the campaign - was the current, predominantly national politics of the individual parties, competing in the elections to the European Parliament in 2014. Often, party election broadcasts attended by the candidates to the European Parliament were used by the anchors as a tool for the discussion about the national politics. Among the specific events that were discussed, we have indicated the problems with the declaration of assets (Aleksander Kwasniewski, the former President of Poland, Donald Tusk and Jaroslaw Kaczynski, the former Prime Ministers of Poland), the crisis in Ukraine, the situation of flood risks, and even the victory of Conchita Wurst at the 2014 Eurovision song contest. Interestingly, the European Union appeared as a central theme only when discussing the issue of a possible energy union and a further integration of the European structures. Other topics or political EU-wide agenda were present to a much lower extent.

\section{Media Logic during Elections}

It is believed that today's daily life cannot be imagined without the media, particularly the mass media. They are omnipresent in politics, economy, education, and arts, as well as other 
public and private spheres of our lives. Besides sleeping and working, we spend most of our time using the mass media (Kepplinger \& Maurer, 2000; McCombs \& Shaw, 1993). They represent the world in the society for the society and they are a significant source of knowledge about the world in which we live (Luhmann, 2000: 1). According to the concept of the "Media Society" and a process of Mediatisation, the media are a societal phenomenon penetrating all areas of modern, globalised societies (Saxer, 2007: 26; Hjarvard, 2008). Therefore, societies act more and more according to the logic of the mass media. The mass media have become important for politics and its actors, as well as for the scientific community and its discourses (Bourdieu, 1996). However, the mass-mediated picture of the world is not a mirror, reflecting the actual reality; rather, the reality as presented in the media is constructed by the media and their mechanisms of selection and presentation styles (Semetko \& Valkenburg, 2000). This fact is especially obvious for topics that are not part of our direct and primary experience. One of the paradigms of the social science research, the social constructivist perspective, argues that the public defines the attributes of risks via a social construct (Berger \& Luckmann, 1966).

As Niklas Luhmann puts it, "[w]hatever we know about our society, or indeed about the world in which we live, we know through the mass media" (Luhmann, 2000:1). Luhmann describes the dual reality of the mass media system. This system occupies a special position in the social structure, providing information and reports to other systems and on other systems. This dual reality is based on two assumptions. The first assumption is the operational closure of the media system, in which the first reality is fabricated. In other words, the first reality of the media is the process of reproducing the media system and differentiating it from other systems. The second assumption is based on what the media perceive as real and what is then reconstructed as this reality. Therefore, the function of the media will be to block the societal self-observation, as well as the self-observation of other functional systems, by imposing their own interpretative framework of the reality. In other words, the media system construes the reality of other systems.

The question that arises from this is: how are the mass media capable of construing reality? The answer lies in the process of thematization, through which the systems communicate. Topics constitute structures of the communication processes, based on generalization. Furthermore, topics represent a reference that is alien to communication, which, on the basis of a system-external differentiation of the information/non-information code, enables the media system to operate and construe the reality.

Above all, a recursive public discussion of the topic is both a typical product of and a requirement for the continuation of the mass media communication. What is more, it ensures that the public recursivity has a retroactive effect upon the communication in the environment of the mass media (Luhmann 2000: 12).

Approaching this concept from a narratological perspective, we can observe a permanent self-reference as a key characteristic of the media content: all pieces of information are combined with each other in the process of autopoiesis, because the (potentially unlimited) mutual referencing is an immanent feature of the media information.

The requirement of recursivity leads to these events being referred to in a subsequent news item - whether they are assigned a meaning that is typical or whether they are woven into a narrative context which can continue to be narrated. Occasionally, incidents that are reported offer an opportunity to report similar events and then to report a 'series' of events (Luhmann 
2000: 33). The mass media form operationally closed systems that can be compared with other social systems, e.g. law, politics, science, business, etc. Secondly, the cognition itself is self-referential and closed: it can only occur in systems.

What does this really mean? It means that the mass media do not present an image of a reality that they have distinguished (this cannot actually be their function), but rather, they themselves create the reality, which they communicate on a daily basis as news, reports, advertisements (the autopoetic relation). Although this reality is a manufactured reality that is formed in a selective manner - and we are all aware of this - it is a socially relevant reality and remains valid while giving us a picture of the actual reality, provided that we understand how it is produced, constructed, and consumed (Bechmann \& Stehr, 2011: 142). What is more, the autopoietic systems are characterised both by a great deal of autonomy, since they are not dependent on external production processes, and by self-reference, since their organisation closes in on itself and their structure is self-defined - it can be any so long as its supports autopoiesis (Mingers, 2002: 294; Maturana \& Varela, 1987: 349).

It must be emphasized that the majority of the current affairs TV programmes covered in the study did not account for the contemporary problems of Europe in a comprehensive and competent way. In most cases, they did not make a diagnosis or a review of the Polish presence in the EU structures and they failed to fully explain the role and function of the European Parliament and other European agencies, such as the European Commission. What is more, they did not allow the Polish viewer-voters to look at the most important achievements and failures of the Polish MEPs. They generally did not define the most significant goals, challenges, and opportunities, faced by the Polish MEPs of the new term. Unfortunately, the Polish European campaign often resembles a national campaign, focused on such issues as home affairs, flood threats, or simple promotional activity of individual political star-locomotives (and their political parties), which largely dominates the current affairs TV programmes devoted to the EP Elections.

\section{Conclusions - Exposure vs. Elections Results}

To sum up, the study confirmed a clear domination of the two, main parties in Poland - PO (Civic Platform) and PiS (Law and Justice) - in the political discourse of the current affairs TV programmes. A group of non-party experts and politicians from these two parties were the main commentators on TV. Moreover, the biggest parties were highly exposed in the current affairs TV programmes during the last two weeks before the 2014 European Elections in Poland. They received the biggest support if we take into account the European Electoral Results (significant, strong r-Pearson correlation between being exposed on television and achieving great electoral results). However, at the same time, the research presents - in the case of small parties - quite an opposite dependency. Namely, we noticed that the parties which were relatively highly exposed on television (such as E+TR (Europa+Your Movement) and SP (Poland Comes First)) did not exceed the electoral threshold. To make it even more complex, we took into consideration the fact that one of the smallest political parties Kongres Nowej Prawicy (Congress of The New Right Wing) - despite a relatively low exposure of their representatives on TV, achieved a good electoral result -7.15 pct. However, it is worth mentioning that this party is well exposed in other media, mainly the Internet, thanks to its many young fans and activists (Sula, 2014).

\section{Autopoetic Discourse of Polish Current Affair TV Programmes}

Strong autopoietic (according to the definition by Luhmann) and autoreferential electoral discourse means that the media are interested primarily in what they "produce," in this case, 
in what they emit. Their narratives relate to themselves and the speeches made by the visitors in programmes constitute a point of reference for the next guests in the subsequent broadcasts. A great number of the journalistic topics in the discussions were the issues concerning the course and dynamics of a political campaign, the manner of its coverage by the media, as well as opinion polls. The essential and actual decisions and processes of making politics were represented to a much lesser extent, which raises the question of the adequacy of the media discourse as a medium of the actual knowledge about the political problems and not simply the knowledge about the rules of self-propelling and autopoetic "game," which is the election campaign. A visible, strongly autopoietic (Bechmann \& Stehr, 2011) journalistic discourse is one which deals mostly with the election campaign itself (how it is conducted, what are the communication strategies of the parties, etc.) and, to a lesser extent, with the substantive issues. According to Bechmann and Stehr (2011: 144), the sector of news and features (including current affairs TV programmes) still corresponds most closely to our everyday expectations of that media function, which is connected with the reproduction of reality. Although information is offered here in a mode of neutrality and objectivity, a closer analysis reveals that the mass media are not greatly interested in truth, let alone the scientifically generated truth. Luhmann no longer proceeds on the basis of a causal relationship between the mass media and the society, which seeks direct effects as if the media were deliberately seeking to manipulate. The media affect the public opinion, but indirectly, by framing particular topics, rather than directly. Each individual piece of information may be wrong, but the topic itself structures the public communication, providing the basis for a further communication (Bechmann \& Stehr, 2011: 146).

It is worth mentioning that an autopoietic system, however, can be perceived also in a different way - it does not transform inputs into outputs. Instead, it transforms itself into itself. What is meant by this is that the outputs of the system, that which it produces, are its own internal components and the inputs it uses are again its own components (it does always require some elements from the environment and it does excrete waste). It is thus in a continual dynamic state of self-production (Mingers, 2002: 280).

Among the substantive issues, the national political issues dominated the discourse, eclipsing the issues at the European level. It also means that the majority of the current affairs TV programmes did not explain the problems of modern Europe in a clear and comprehensive way, as have been already mentioned before. As Luhmann argues, ,[i]t is the topics of communication which ensure that the mass media, in spite of their operational closure, do not take off, do not take leave of society. Topics are an unavoidable requirement of communication. They represent communication's other-reference. They organize communication's memory. They gather contributions into complexes of elements that belong together, so that it can be discerned in the course of communication whether a topic is being retained and carried forward or whether it is being changed. At the level of topics, then, other-reference and self-reference are constantly being coordinated in relation to each other within the system's own communication" (Luhmann, 2000: 12). It is clear that the media operate highly selectively, so that they do not function as a mirror and channel for the public, but rather, they generate their own reality. Any piece of information can be accepted or rejected, creating the possibility of bifurcation in a further communication, without the need to assume an underlying plan or genuine reality (Bechmann \& Stehr, 2011: 146).

Finally, we can agree once more with Niklas Luhmann, who says that "[w]e know so much about the mass media that we are not able to trust these sources" (Luhmann, 2000:1). 


\section{Discussion - Autopoetic and Second-Order Election}

To sum up, according to the already mentioned concept of the European Elections as the Second-Order Elections (SOEs), the media does not help to break the "vicious" cycle of the second-order voting by offering domesticized themes during the campaign. In that sense, the EP Elections fail as an instrument of democracy, namely they fail to express the will of the European people on the European issues (Mair and Thomassen, 2010), and do not help to redress the EU democratic deficit, but rather, they intensify it (Compare to Adam, Maier \& Kaid, 2009; Peter \& De Vreese, 2004). We have to remember that the process of the European Elections is nationally framed and dominated by national and political issues, which naturally supports the autopoetic thematisation (self-referential themes of a campaign), acting to the detriment of the most crucial aspects of the European Elections.

The crux of this paper is that the more autopoetic a political discourse during the last two weeks before the elections is (according to the phenomenon of thematisation commented on in this paper), especially when it comes to the European Elections, which seem to be the Second-Order Elections (De Vreese et al., 2006; De Vreese, 2009; Irwin, 1995; Norris \& Reif, 1997; Weber, 2007), the more misunderstood the viewers-voters feel about the main functions, goals and institutions of the European Union (including the European Parliament). What is more, it generates a general social apathy and common discouragement for the political participation in the elections (voter turnout in Poland during the last European Elections: 2004 (the first ones) - 20.87 pct, 2009 - 24.53 pct, $2014-23.83$ pct. See: Tuman, 2008). This perspective should be one of the most challenging topics for the researchers on the European Union, especially in times of the rising separatisms and national particularisms in almost every EU country. 
References:

Adam, S., \& Maier, M., \& Kaid, L.L. (2009), Codebook ofContent Coding: Strategies of Party Campaigns in the Context ofthe EP Elections. Berlin/Landau

Kováŕ, J. \& Kovář, K. (2012), National or European? EP Election Campaign Themes in the News Media, "European Electoral Studies", Vol. 7, No. 1, pp. 30-41.

Bechmann, G., Stehr, N. (2011), Niklas Luhmann's Theory of the Mass Media, "Society", March, vol. 48, iss. 2, pp. 142-147.

Bennett, W. L., Entman, R. M. (2001), Mediated politics: communication in the future of democracy. Cambridge: Cambridge University Press.

Berger, P. L. \& Luckmann, T. (1966), The Social Construction of Reality. A Treatise in the

Sociology of Knowledge. Alien Lane, London.

Blumler, J. G., ed. (1983), Communicating to Voters: Television in the First European Parliamentary Elections. London: Sage.

Bolin, G., (2014), Television Journalism, Politics, and Entertainment: Power and Autonomy in the Field of Television Journalism, "Television \& New Media", May, Vol. 1,5 Issue 4, pp. 336-349.

Boyatzis, R. E. (1998), Transforming qualitative Information: thematic analysis and code deoelopment. London: Sage Publications.

Bourdieu, P. (1996), Sur la television, Liber-Raisons d'agir, Paris.

De Vrees, C. E., et al. (2011), Individual and contextual variation in EU issue voting: The role of political information. "Electoral Studies". Vol. 30, No. 1, pp. 16-28.

De Vrees, C. E. (2009): Second-Rate Election Campaigning? An Analysis of Campaign Styles in European Parliamentary Elections. "Journal of Political Marketing". Vol. 8, No. 1, pp. 7-19.

European Commission (1999-2007): Public Opinion in the European Union. Brussels: European Commission.

European Commission (2004): Flash Eurobarometer: Post European Elections 2004 Survey. Brussels: European Commission.

Ferrara, F., \& Weishaupt, T. J. (2004), Get your Act Together: Party Performance in European Parliament Elections. "European Union Politics". Vol. 5, No. 3, pp. 283306.

Freire, A., Teperoglou, E. (2007), European Elections and National Politics: Lessons from the "New" Southern European Democracies. "Journal of Elections, Public Opinion \& Parties". Vol. 17, No. 1, pp. 101-122.

Hjarvard, S. (2008), The mediatization of society: A theory of the media as agents of social and cultural change, "Nordicom Review", vol 29, no. 2, pp. 105-134.

Hix, S., Marsh, M. (2007), Punishment or Protest? Understanding European Parliament Elections. "The Journal of Politics". Vol. 69, No. 2, pp. 495-510.

Hollander, B. A., (2014), The Surprised Loser: The Role of Electoral Expectations and News Media Exposure in Satisfaction with Democracy, "Journalism \& Mass Communication Quarterly", December, Vol. 91 Issue 4, pp. 651-668.

Irwin, G. (1995), Second-order or Third-rate?-Issues in the Campaign for the Elections for the European Parliament 1994. "Electoral Studies". Vol. 14, No. 2, pp. 183-199.

Jalali, C., Silva, T. (2011): Everyone Ignores Europe? Party Campaigns and Media Coverage in the 2009 European Parliament Elections. In Maier, M., Strömback, J., Kaid, L. L., eds. Political Communication in European Parliamentary Elections. Farnham: Ashgate.

Kepplinger, H. M., \& Maurer, M. (2000). Der Zwei-Stufen-Fluß der Massenkommunikation. Anmerkungen zu einer nie bewiesenen und längst überholten These der Wahlforschung. In: M. Klein, W. Jagodzinski, E. Mochmann \& D. Ohr (Hrsg.), 50 
Jahre Empirische Wahlforschung in Deutschland. Entwicklung, Befunde, Perspektiven, Daten. (pp. 444-464). Wiesbaden: Westdeutscher Verlag.

Koopmans, R. (2007), Who inhabits the European public sphere? Winners and losers, supporters and opponents in Europeanised political debates. "European Journal of Political Research". Vol.46, No. 2, p. 183-210.

Kriesi, H. (2007), The Role of European Integration in National Election Campaigns. "European Union Politics". Vol. 8, No. 1, pp. 83-108.

Krippendorff, K. (1980), Content analysis. An introduction to its methodology, Beverly Hills: Sage.

Luhmann, N. (2000) [1996], The Reality of Mass Media, Stanford, CA: Stanford University Press.

McCombs, M.E., \& D.L. Shaw. (1993), The Evolution of Agenda-Setting Research: TwentyFive Years in the Marketplace of Ideas. "Journal of Communication". Vol. 43, No. 2, pp. 58-67.

Mair, P., \& Thomassen, J. (2010): Political representation and government in the European Union. "Journal of European Public Policy". Vol. 17, No. 1, pp. 20-35.

Maturana, H. R. \& Varela, F. J. (1987). The tree of knowledge: The biological roots of human understanding. Boston: Shambhala Publications.

Mingers, J. (2002), Can social systems be autopoietic? Assessing Luhmann's social theory, "The Editorial Board of The Sociological Review", pp.279-299

Norris, P., Reif, K. (1997), Second-order elections. "European Journal of Political Research". Vol. 31, No. 1, pp. 109-124.

Peter, J., De Vreese, C. H. (2004): In Search of Europe: A Cross-National Comparative Study of the European Union in National Television News. "The Harvard International Journal of Press/Politics". Vol.9, No.4, pp.3-24.

Reif, K., \& Schmitt, H. (1980): Nine Second-Order National Elections - A Conceptual Framework For the Analysis of European Elections Results. "European Journal of Political Research". Vol. 8, No. 1, pp. 3-44.

Reif, K. (1984), National Electoral cycles and European elections 1979 and 1984. "Electoral Studies". Vol. 3, No. 3, pp. 244-255.

Saxer, U (2007). Politik als Unterhaltung. Zum Wandel politischer Öffentlichkeit in der Mediengesellschaft. Konstanz: UVK.

Schuck, A. R. T., Vliegenthart, R., Boomgaarden, H. G., Elenbaas, M., Azrout, R., van Spanje, J., de Vreese, C. H., Explaining Campaign News Coverage: How Medium, Time, and Context Explain Variation in the Media Framing of the 2009 European Parliamentary Elections, "Journal of Political Marketing”, Vol. 12 Issue 1, pp. 8-28.

Semetko, H. M., \& Valkenburg, P. M. (2000), Framing European politics: a content analysis of press and television news, "Journal of Communication", June, Volume 50, Issue 2, pp. 93-109.

Strömback, J. \& Shehata, A. (2010), Media malaise or a virtuous cirde? Exploring the causal relationships between news media exposure, political news attention and political interest.

Sula, P. (2014), The 2014 European Elections The Case of Poland, Studia Politica: Romanian Political Science Review, Vol. 14 Issue 3, pp. 395-406.

"European Journal of Political Research". Vol.49, No. 5, pp. 575-597.

Tuman, J. S. (2008), Political Communication in American Campaigns, San Francisco: SAGE

Weber, T. (2007), Campaign Effects and Second-Order Cycles: A Top-Down Approach to European Parliament Elections. "European Union Politics". Vol. 8, No. 4, pp. 509536. 